\title{
Case Report: Diagnosis and Treatment of Enteritis Caused by Bacterial in a Dog
}

\author{
Mungky Ema Ramadhani $^{1}$, Soedarmanto Indarjulianto ${ }^{2 *}$, Yanuartono $^{2}$, Alfarisa \\ Nururrozi $^{2}$, Slamet Raharjo ${ }^{2}$, and Alagenthirah Nakkeeran ${ }^{3}$ \\ ${ }^{1}$ Faculty of Veterinary Medicine, Universitas Gadjah Mada, Jl. Fauna 2, Karangmalang, Yogyakarta \\ 55281, Indonesia \\ ${ }^{2}$ Department of Internal Medicine, Faculty of Veterinary Medicine, Universitas Gadjah Mada, Jl. \\ Fauna 2, Karangmalang, Yogyakarta 55281, Indonesia \\ ${ }^{3}$ Rimba AcademyNo. 50, Jalan 2/87G, Taman Seputeh, 58000 Kuala Lumpur, Wilayah Persekutuan, \\ Malaysia.
}

\begin{abstract}
Diagnosis of the cause of enteritis in dogs greatly influences the success of its treatment. This case report describes the management of a male dog, 5 months old, $4.8 \mathrm{~kg}$ body weight which reported diarrhea, fever and no appetite. The physical examination showed the dog had diarrhea, lethargy, anemic mucous membranes, body temperature of $39.6{ }^{\circ} \mathrm{C}$ and an increase in intestinal peristalsis. The results of blood tests showed normochromic microcytic anemia, decreased hemoglobin and PCV, lymphocytopenia, and eosinopenia. The results of the stool examination identified Escherichia coli, Aeromonas hydrophila and coliform. The dog is diagnosed with bacterial enteritis with a good prognosis. Treatment is given for 5 days with intramuscular injection of amoxicillin at a dose of 10 $\mathrm{mg} / \mathrm{kgBW}$ bid, diphenhydramine $\mathrm{HCl}$ at a dose of $2 \mathrm{mg} / \mathrm{kgBW}$ bid, multivitamin syrup $0.1 \mathrm{ml} / \mathrm{kgBW}$ bid orally, and intramuscular injection of iron dextran at a dose of $10 \mathrm{mg} / \mathrm{kgBW}$ only on the fifth day. It was concluded that the dog had enteritis due to bacterial infection, and it recovered after 5 days of treatment.
\end{abstract}

Keywords: bacterial, dog, enteritis, Escherichia coli, Aeromonas hydrophila.

\section{Introduction}

Enteritis is inflammation of the intestine that is often found in dogs, especially puppies. This disease can be caused by non-infectious or infectious agents. Some of the infectious agents that have been found in dogs with enteritis are viruses, bacteria, parasites and fungi. The incidence of enteritis in dogs, especially puppies is very large and often causes death [1-5].

Enteritis in dogs has been widely reported in various countries in all breeds with various infectious agents as causes [6-8]. The mortality rate for enteritis can be as high as $10 \%$ in treated dogs with parvovirus [8]. The bacterial infection that causes urethritis can be a primary or secondary cause. Secondary bacterial infection is frequently reported in cases of

\footnotetext{
* Corresponding author: indarjulianto@ugm.ac.id
} 
canine parvo virus (CPV) infection [8-9]. The presence of an infection caused by a mixed caustive agent will make diagnosis and therapy more difficult. Usually enteritis in dogs is characterized by diarrhea, but the cause of the diarrhea cannot be easily distinguished without further examination. Therefore, examination of patients suffering from enteritis must be done carefully and need confirmation through laboratory examination.

Determination of the diagnosis and treatment of enteritis by veterinarians is very demanding to be fast and precise. The obstacle that is often faced by vet practitioners is the limited facilities and infrastructure for supporting laboratories. Another problem is that the time to determine the causative agent of enteritis, especially bacteria, viruses and fungi, still takes too long, so that the diagnosis and treatment are determined based on clinical symptoms [4]. Therefore a reference is needed for a faster approach to diagnosis and therapy. This case report aims to determine the diagnosis and treatment of a dog patient suffering enteritis and evaluate the results. This case report is expected to provide additional references for veterinarians to make decisions on diagnosis and treatment of dog enteritis.

\section{Materials and Methods}

\subsection{Materials}

This case report uses a 5-month-old male mixed breed dog weighing $4.8 \mathrm{~kg}$ who is being treated at the Veterinary Clinic of the Department of Internal Medicine, Faculty of Veterinary Medicine, Gadjah Mada University. The supporting samples examined were blood for hematological examination and feces for parasites, fungi and bacteria confirmation.

\subsection{Methods}

Examinations carried out include the history, physical examination and laboratory examination. Laboratory examinations include hematological examination, stool examination and microbiological examination. Hematological examination included counting erythrocytes, hemoglobin, hematocrit, total leukocytes, differential leukocytes, total plasma protein, and fibrinogen which were carried out on the day before therapy and after therapy $[4,10]$.

Endoparasite examination was carried out using native tests and centrifuge tests and microbiological examinations by culturing fecal samples on Blood agar plates (BAP, Merck Millipore, Germany), Harlequin TM E. coli / Coliform Medium (ECM, Neogen, UK) and Sabouraud Dextrose Agar ( SDA, Merck Millipore, Germany) to see the presence of microorganisms in feces, using the method that has been done previously [4, 11].

The therapy given was amoxicillin (Amoxsan, Sanbe Farma, Indonesia) at a dose of 10 $\mathrm{mg} / \mathrm{kgBW}$, and diphenhydramine $\mathrm{HCl}$ (Veterdryl, PT Duta Kaisar Pharmacy, Indonesia) at a dose of $2 \mathrm{mg} / \mathrm{kgBW}$ intramuscularly 2 times a day for 5 days. Supportive therapy as multivitamin syrup (Erela, Indonesia) was given orally, dose $0.1 \mathrm{ml} / \mathrm{kgBW} 2$ times a day for 5 days. Anemia that occurs is treated with iron dextran (Jiangxi Bolai Pharmacy, China) a single dose of $10 \mathrm{mg} / \mathrm{kg}$ body weight intramuscularly on the fifth day [12]. Patients were hospitalized and the progress of therapy was observed every day, and analyzed descriptively.

\section{Results}

The anamnesis showed that the dog had no appetite since 2 days before being examined, and the day before coming to the dog clinic had diarrhea with a liquid consistency. This dog was 
kept together in an environment with an outbreak of CPV and there have been deaths in several dogs. Physical examination showed the dog has diarrhea, weakness, anemic mucous membranes, body temperature $39,6{ }^{\circ} \mathrm{C}$, there was increased intestinal peristalsis and found some Rhipiycephalus sanguineus on the skin. The results of hematological examination before therapy showed microcytic normochromic anemia with a decrease in the number of erythrocytes $\left(3,38 \times 10^{6} / \mathrm{mm}^{3}\right), \mathrm{Hb}(7,2 \mathrm{~g} / \mathrm{dL}), \mathrm{PCV}(20 \%)$, eosinofil $\left(0 \mathrm{cell} / \mathrm{mm}^{3}\right)$, and lymphocyte $\left(633 \mathrm{cell} / \mathrm{mm}^{3}\right)$ (Table 1$)$.

The parasitic examination of fecal samples using native and centrifuge tests showed that the dog was not infected by worm endoparasites or protozoa. The results of bacterial culture on BAP were grew 2 different colonies. The first colony grew with a $\beta$-hemolytic zone, is grayish in color, flat and the whole colony is round with a large colony diameter. The results of Gram staining showed Gram negative with rather large bacillus-shaped cells, so it was identified as Aeromonas sp. The second colony grew on ECM media and obtained 2 different colonies, namely the blue colony as Escherichia coli and purple as coliform. The results of Gram staining showed Gram negative with small bacillus-shaped cells (Fig. 1). The results of culture fecal samples on SDA media did not show fungal growth.

Hematological examination results after therapy showed an increase in the number of erythrocytes $\left(3,81 \times 10^{6} / \mathrm{mm}^{3}\right)$, decrease of $\mathrm{Hb}(6,8 \mathrm{~g} / \mathrm{dL})$, and still suffer from hyperchromic microcytic anemia with PCV $18 \%$ (Table 1).
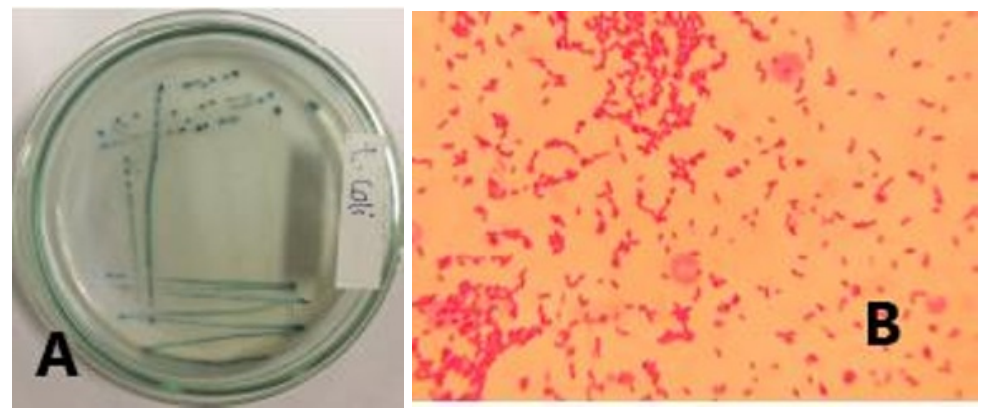

Fig. 1. E. coli from dog feces on ECM agar (A), and result of Gram staining as Gram negative (B)

Table 1. Results of blood test performed.

\begin{tabular}{|c|c|c|c|c|}
\hline Examination & Unit & $\begin{array}{c}1^{\text {st }} \text { day } \\
\text { pre- } \\
\text { therapy }\end{array}$ & $\begin{array}{c}4^{\text {th }} \text { day post- } \\
\text { therapy }\end{array}$ & $\begin{array}{c}\text { Standard } \\
{[13]}\end{array}$ \\
\hline Erythrocytes & $10^{6} \mathrm{sel} / \mu \mathrm{L}$ & 3,38 & 3,81 & $5,5-8,5$ \\
\hline Hemoglobin & $\mathrm{g} / \mathrm{dL}$ & 7,2 & 6,8 & $12,0-18,0$ \\
\hline $\mathrm{PCV}$ & $\%$ & 20 & 18 & $37-55$ \\
\hline $\mathrm{MCV}$ & $\mathrm{fL}$ & 59,17 & 47,24 & $60-77$ \\
\hline $\mathrm{MCH}$ & $\mathrm{Pg}$ & 36 & 37,77 & $32-36$ \\
\hline Leucocytes & $10^{3} \mathrm{sel} / \mathrm{mm}^{3}$ & 10.550 & 8.350 & $\begin{array}{l}6.000- \\
17.000 \\
\end{array}$ \\
\hline $\begin{array}{ll}\text { Neutrophil } & \mathrm{R} \\
& \mathrm{A} \\
\end{array}$ & $\begin{array}{c}\% \\
10^{3} \mathrm{sel} / \mathrm{mm}^{3} \\
\end{array}$ & $\begin{array}{c}88 \\
9,284 \\
\end{array}$ & $\begin{array}{c}67 \\
5,594 \\
\end{array}$ & $\begin{array}{c}45-64 \\
2,5-12,5\end{array}$ \\
\hline
\end{tabular}




\begin{tabular}{|cl|c|c|c|c|}
\hline Lymphocyte $\mathrm{R}$ & $\%$ & 6 & 25 & $27-36$ \\
& $\mathrm{~A}$ & $10^{3} \mathrm{sel} / \mathrm{mm}^{3}$ & 633 & 2,087 & $1,5-7,5$ \\
\hline Monocytes & $\mathrm{R}$ & $\%$ & 6 & 6 & $0-5$ \\
& $\mathrm{~A}$ & $10^{3} \mathrm{sel} / \mathrm{mm}^{3}$ & 633 & 501 & $0-0,9$ \\
\hline Eosinophil & $\mathrm{R}$ & $\%$ & 0 & 2 & $0-4$ \\
& $\mathrm{~A}$ & $10^{3} \mathrm{sel} / \mathrm{mm}^{3}$ & 0 & 167 & $0-0,8$ \\
\hline
\end{tabular}

\section{Discussion}

The dog in this case was mainly diagnosed suffered enteritis caused by bacteria with a prognosis of fausta. This is determined based on the clinical symptoms of diarrhea, an increase in body temperature and is supported by the results of examination of blood samples in the form of anemia and normal leukocyte counts. The results of the stool examination identified several bacteria, but there were no gastrointestinal parasites and fungi, indicating that the main cause was bacteria. $\beta$-hemolysis bacteria that grow on BAP media are Gram negative bacteria, in the form of bacilli, so that it suspected as Aeromonas sp. However, further tests to be sure need to be done both phenotypically and genotypically. According to [14] Aeromonas hydrophila has a gray, hemolytic, flat, round colony with a diameter of 2.0$3.0 \mathrm{~mm}$. These bacteria are found in many aquatic habitats and when ingested by dogs can infect the mucosa of the instestine and produce enterotoxins that cause acute watery diarrhea [15].

Another bacterium that found in this case is Escherichia coli. This is based on the presence of colony growth in BAP, and showed a purple colony on EMC, small bacilli cells and Gram negative on Gram stain. According to [16] E. coli is bacillus-shaped, small, pink in color, and Gram negative. The form of colony findings on BAP media is also in accordance with [14], that the colony is gray, smooth, shiny and round in shape with a diameter of 2.0$3.0 \mathrm{~mm}$. Other bacteria that grow on purple ECM media are coliform bacteria, but to differentiate between bacterial species, further biochemical tests should be carried out. Coliform bacteria are Gram negative, pink in color and bacilli shaped on Gram stain [17]. The bacterial colonies of Klebsiella pneumonia and Enterobacter aerogenes have the same form of fused mucoid colonies with a diameter of 2.0-4.0 mm and are gray in color [14]. Some strains of $E$ coli are normal flora in the digestive tract of dogs, but some strains are pathogenic and can cause gastrointestinal disturbances [18-19].

This canine enteritis is probably a continuation of the previous disease suspected of being exposed to CPV infection. According to information from the owner, dogs were kept together with other dogs that died from Parvo infection. The incubation period for the parvo virus is 7-14 days [20] (Jane E. Sykes, 2014 ). Damage to the intestinal villi epithelium can stimulate secondary bacterial infection by E. coli [8-9]. Escherichia coli is a bacterium Enterobacteriaceae, most of which are normal flora in the digestive tract of animals, but some are pathogenic so they can cause diarrhea [17]. Coliform bacteria can produce acids and gases in lactose fermentation. Several bacteria including other coliform bacteria include Klebsiella pneumonia and Enterobacter aerogenes [17]. Other bacteria found in CPV-infected dog feces are Shigella, Peptoclostridium, Peptostreptococcus, Streptococcus, Fusobacterium, Salmonella sp., Campylobacter sp., while parasitic agents that have been found are protozoa (coccidia, giardia, toxoplasma), or intestinal parasites (nematodes, cestodes) [21-22]. Bacterial co-infection can increase the severity of the lesions as well as clinical signs. Parvo virus can be found in the feces for the first time on the 3rd day after infection, and appears most frequently and in greatest numbers on days 4 to 7 after infection, and falls sharply thereafter. Serum antibodies were first detected on day 5 after infection with high titres from 
day 7 onwards. Virus isolation from serum samples showed non-cell-associated viraemia at 3 and 4 days after inoculation [23].

The therapy given in this dog has been able to improve the dog's physical health condition. Antibiotics should be based on a bacterial sensitivity test. However, due to time constraints, sensitivity testing cannot be performed, the choice of drug refers to the results of previous sensitivity tests (4). After treatment, the dog physically showed improved health status. As long as the dog is treated in a stationary unit, the dog did not show digestive disorders such as vomiting or diarrhea. The dog's appetite on the first day to the third day only wants to eat a bit, but starts on day 4 get better and better. On the 5 th day the dog is able to routinely defecate with normal consistency and color. The physical condition after treatment has not been seen significantly in the blood profile which is still anemic, but there has been an increase in the number of erythrocytes from $3,38 \times 10^{6} \mathrm{cell} / \mathrm{mm}^{3}$ to $3,81 \times 10^{6} \mathrm{cell} / \mathrm{mm}^{3}$. This can happen because when the second blood was taken, the dog was still being treated.

\section{Conclusion}

Based on the results of the history, physical and laboratory examinations in the form of a hematological, fecal and microbiological examination, the dog was diagnosed suffering enteritis due to infection by Escherichia coli, Aeromonas sp. and coliform bacteria. Five days of amoxicillin, diphenhydramine $\mathrm{HCl}$ and multivitamin syrup treatment, as well as a single dose of Fe preparations have increases health status.

\section{References}

1. C. Miranda, G. Thompson. Journal of General Virology. 97 (2016)

2. S. De, M.P. Gupta, L.D. Singla, N.K. Sood. Journal of Animal Research: 7, 2 (2017)

3. M.E. Abd Alfatah. JSM Vet Med Res 2: 7 (2019)

4. R.A. Dewandaru, S. Indarjulianto, Y. Yanuartono, A. Nururrozi, H. Purnamaningsih, Rusmihayati. JIPVET. 9, 2 (2019)

5. H. Purnamaningsih, S. Indarjulianto, Yanuartono, A. Nururrozi, I. Widiyono, Rusmihayati. JSV. 38, 2 (2020)

6. L.E. Carmichael. J. Vet. Med. Series B. 52, 7-8 (2005)

7. W.J. Botha, J.P. Schoeman, S.L. Marks, Z. Whitehead, C.H. Annandale. J. S. Afr. Vet. 89, (2018)

8. S. Qi, J. Zhao, D. Guo, D. Sun. Front. Vet. Sci., 20 (2020)

9. I.B.O. Winaya, I.K. Berata, A.A.A.M. Adi, I.M Kardena. Jurnal Kedokteran Hewan 8, 2 (2014)

10. R.E. Englar. Performing the Small Animal Physical Examination. (First Ed. John Wiley \& Sons, Inc. USA., 2017)

11. S. Indarjulianto, Yanuartono, H. Purnamaningsih, P. Wikansari, G.Y.I. Sakan, J.Vet. 15, 2, (2014)

12. D.C. Plumb, D. Pharm. Plumb's Veterinary Drug Handbook 6th Edition. (Iowa:Blackwell Publishing, 2008)

13. D.J. Weiss, K.J. Wardrop. Schalm's Veterinary Hematology. USA: Wiley Blackwell, 2011) 
14. B. Markey, F. Leonard, M. Archambault, A. Cullinane, D. Maguire. Clinical Veterinary Microbiology 2nd Edition. (Mosby Elsevier. China, 2013)

15. P.J. Quinn, B.K. Markey, F.C. Leonard, E.S. FitzPatrick, S. Fanning, P.J. Hartigan. Veterinary Microbiology and Microbial Disease 2nd Edition. (Wiley-Blackwell. Iowa., 2011)

16. M.A. Zinnah, M.R Bari, M.T. Islam, M.T. Hossain, M.T. Rahman, M.H. Haque, , S.A.M. Babu, R.P. Ruma, M.A. Islam. Bangl. J. Vet. Med. 5, 1-2 (2007)

17. M. J. Leboffe, B.E. Pierce. A Photographic Atlas for The Microbiology Laboratory 4th Edition. (Morton Publishing Company. USA., 2011)

18. K. Kamilia Younis, M. Baddour, M.S. Ibrahim. J. Vet. Sci. 45 (2015)

19. A.B. Kjaergaard, A.P. Carr, M.C. Gaunt. Can Vet J. 57 (2016)

20. J.E. Sykes. Canine and Feline Infectious Disease.141-151 (2014)

21. D.M.Eldredge, D.G.Carlson, L.D. Carlson, J.M. Giffin.Cat Owner's Home Veterinary Handbook 3rd Edition. (Wiley Publishing, Inc. New Jersey, 2008)

22. Y. Zheng, X. Hao, X. Lin, Q. Zheng, W. Zhang, P. Zhou, S. Li. Microbial Pathogenesis, 121 (2018)

23. L. Macartney, I.A. McCandlish, H. Thompson. H.J. Cornwell. Vet Rec.115, 18 (1984) 